\title{
Siyasal İletişim Araçlarının Oy Verme Davranışı Üzerindeki Etkisi: 2017 Referandumu Üzerine Bir Araştırma ${ }^{1}$
}

\author{
Emre Çolakoğlu²
}

Ahmet Tan ${ }^{3}$

Siyasal İletişim Araçlarının Oy Verme Davranışı Üzerindeki Etkisi: 2017 Referandumu Üzerine Bir Araştırma

Öz

16 Nisan 2017 Anayasa değişikliği referandumunda, seçmenlerin oy tercihleri üzerinde etkili olan siyasal iletişim araçlarının etkisini incelemek amacıyla yapılan bu çalışmada, Gaziantep'te 495 katılımcıyla yüz yüze anket gerçekleştirilmiştir. Yapılan İkili Lojistik Regresyon analizi sonucunda liderlerin Televizyon Konuşmalarından etkilenme düzeyindeki bir birimlik artışın evet oyu verme olasılığını, Mitinglerden etkilenme düzeyindeki bir birimlik artışın evet oyu verme olasılığını, Gazete Köşe Yazılarından etkilenme düzeyindeki bir birimlik artışın da hayır oyu kullanma olasılığını arttırdığı görülmüştür. Referandumların kendine has özellikleri, 16 Nisan 2017 referandumunun Türk seçmeni açısından önemi ve bu konuda yapılmış çalışmaların sınırlı olması nedeniyle bu çalışma ve elde edilen sonuçlar, ilgili alandaki boşluğu doldurmaya yardımcı niteliktedir.

Anahtar Kelimeler: Politik Pazarlama, Siyasal İletişim, Seçmen Davranışı, Referandum, Lojistik Regresyon
The Effect of Political Communication Tools on Voting Behavior: A Research on the $\mathbf{2 0 1 7}$ Referendum

Abstract

A face-to-face survey was conducted in Gaziantep with 495 participants in order to investigate the effect of political communication tools on voters' voting preferences in the constitutional amendment referendum of April 16th, 2017. Binary Logistics Regression analysis showed that a unit increase in the level of influence from leaders' TV speeches increased the likelihood of yes voting, a unit increase in the level of influence from the rallies increased the likelihood of yes voting, and a unit increase in the level of influence by newspaper column writings increased the likelihood of no voting. The specific characteristics of the Referendums, the importance of the April 16th, 2017 referendum for the Turkish electorate, and the limited work done in this regard, this work and the results obtained help to fill the gap in the relevant area.

Keywords: Politic Marketing, Political Communication, Voter Behavior, Referendum, Logistics Regression

\section{Giriş}

Referandum (halk oylaması), halkın karar alma süreçlerine doğrudan katılımını sağlayan demokratik yöntemlerden biridir (Özdemir, 2017). Referandum oylamaları Türkiye'de çok partili sistemin başlamasından bu yana sadece yedi defa gerçekleştirilmiş ender bir yöntemdir (Doğan, 2017). 16 Nisan 2017 tarihinde yapılan referandum, diğerlerinden farklı olarak ülke yönetim şeklinde köklü değişimler meydana getiren anayasa maddesi değişikliklerini halkın oyuna sunduğundan, Türkiye siyasi hayatında bir dönüm noktası olarak değerlendirilebilecek kadar önemlidir. Demokratik sisteme geçişten bu yana yönetim şekli olarak kullanılan parlamenter sistem yerine, başkanlık sisteminin Türkiye'ye uyarlanmış şekli olarak görülebilen partili cumhurbaş-

\footnotetext{
${ }^{1}$ Bu çalışma 12-14 Nisan 2018 tarihlerinde gerçekleştirilen 3. Lisansüstü İşletme Öğrencileri Sempozyumu'nda sözlü olarak sunulmuş bildirinin genişletilmiş halidir.

2 Doktora Öğrencisi, Gaziantep Üniversitesi, Sosyal Bilimler Enstitüsü, İşletme ABD, colakogluemre@gmail.com, yazar ORCID bilgisi: https://orcid.org/0000-0002-0075-4684.

${ }^{3}$ Dr. Öğr. Üyesi, Gaziantep Üniversitesi, IỉBF, İşletme Bölümü, Atan02@gmail.com, yazar ORCID bilgisi: https://orcid.org/0000-0001-9972-4372.
} 
kanlığı sistemine geçişi ön gören maddeleri oylayacak olan seçmenler açısından maddelerin değerlendirilmesi ve oy kararının verilmesi alışıla gelmiş siyasal seçim süreçlerinde olduğundan daha karmaşık ve yeni bir süreç olmuştur.

Politik pazarlama ve siyasal iletişim açısından bakıldığında referandumlar ve siyasal seçimler (genel veya yerel) birbirlerinden farklı yöntemlerdir (Laycock, 2013; LeDuc, 2002). Siyasal seçimler, yönetime talip olan parti ve adayların seçmenler tarafından belirlenmesini sağlayan bir yöntemken referandumlar, anayasa değişiklikleri için olduğu kadar temel sosyal, siyasal ve mali konuların halkın tercihine sunulması şeklinde de olabilmektedir (Bowler ve Donovan, 2002). Bu tür referandumlara en güncel örnek Birleşik Krallık'ın Avrupa Birliğinde kalıp kalmaması kararının halk oylamasına sunulduğu ve "Brexit" olarak da bilinen referandumdur. Referandumların siyasal seçimlerden bir diğer farkı da oy pusulalarında, politik çağrışımlar yapacak parti amblemi ya da aday ismi gibi öğeler yerine evet ve hayır gibi iki seçeneğin bulunmasıdır (LeDuc, 2002).

Genellikle referandumlarda oylanan konu seçmen açısından yeni ve yabancı olduğu için seçmenler öğrenme ve oy tercihlerini belirlemede bir ipucu arayışı içinde olurlar ve çeşitli kaynaklardan bilgi edinerek oylarını belirlerler (LeDuc, 2000). Bu kaynaklar genellikle ideolojik yönelimler, partiler ya da politik liderler olduğundan, politik içerik asıl oylanan konunun önüne geçebilir (Quinlan vd., 2015). Hem seçmenlerin bilgi edinme ihtiyacı hem de politik aktörlerin seçmen davranışlarını etkileyerek, hedefledikleri sonuçlara ulaşabilmeleri için referandum kampanyası boyunca siyasal iletişim yöntemlerinin etkin kullanılması ve bu yöntemlerin ne derece etkili olabileceğinin bilinmesi politik pazarlama ve siyasal iletişim açısından büyük önem taşımaktadır (Avcı ve Hülür, 2017; Çavuşoğlu ve Pekkaya, 2015). Buradan hareketle bu çalışmanın amacı, 16 Nisan 2017 anayasa değişikliği referandumunda siyasal iletişim yöntemlerinin seçmenlerin oy verme davranışı üzerindeki etkisini araştırmaktır. 16 Nisan 2017 referandumunun önemi, referandumların alışılagelmiş seçimlerden farklı oluşu, bu alanda yapılmış çalışmaların azlığı ve kullanılan analiz yöntemi sayesinde siyasal iletişim araçlarının oy tercihleri üzerindeki etkinin doğrudan belirlenmesi nedeniyle elde edilen sonuçlar ilgili akademik alana ve politik aktörlerin pazarlama ve iletişim stratejilerine katkı sağlayacak niteliktedir.

\section{Kavramsal Çerçeve ve Literatür}

Politik pazarlama, parti ya da adayların hedef seçmen kitlesine ulaşması ve benimsenmesi, hedef seçmen kitlesinin olabildiğince arttırılması, rakip parti ve adaylardan farklılaşması ve en az maliyetle politik hedeflere ulaşması için kullanılan tekniklerin tümüdür (Tan, 2002). Bu tekniklerden en önemlisi, parti ve politik aktörlerin savundukları ve kabul ettirmeye çalıştıkları politik mesajın seçmenlere aktarılması olarak tanımlanan propagandadır (Eroğlu ve Bayraktar, 2010). Propaganda faaliyetlerinin gerçekleştirilebilmesi için miting, televizyon ve radyo yayınları, gazeteler, internet ve sosyal medya, açık hava ilanları ve billboardlar, el ilanı, broşür ve kitapçık (Kalender, 2003) gibi siyasal iletişim araçlarının etkin olarak kullanılması ve bunların seçmenler üzerindeki etkisinin bilinerek uygulanması gerekmektedir. Literatürde bu amaçla yapılan çalışmalar incelendiğinde farklı seçmen grupları ve kampanya dönemlerinde bu araçların farklı etkiler sergilediği görülmektedir.

Brians ve Wattenberg (1996) 1992 yılındaki Amerika Birleşik Devletleri başkanlık seçimini inceledikleri çalışmada, televizyon haberleri, gazete yayınlarının ve hatırda kalan reklamların seçmenlerin oy tercihleri üzerinde etkili olduğu; Eveland ve Scheufele (2000) ise 1996 Amerikan başkanlık seçimi kampanyası boyunca yaptıkları çalışmada, seçmenlerin politik bilgi edinme bakımından televizyon ve gazete kullanımının farklılaştığını, bunların da seçmenlerin oy verme ve kampanyaya katılım davranışı üzerinde etkili olduğu sonucuna varmışlardır. Druckman (2005) 
2000 yılındaki Minnesota senato seçim kampanyasını incelediği çalışmada, televizyon ve gazetelerin politik içerik bakımından farklılık göstermediği, buna karşın kampanyayı televizyondan takip edenlerle gazeteden takip edenler arasında nicelik bakımından büyük fark olmasına rağmen, seçmen tercihlerini gazetelerdeki politik içeriklerin televizyondakilerden daha fazla etkilediğini gözlemlemiştir.

Kalender (2003) Konya'da seçmenlerin oy verme davranışlarında etkili olan iletişim araç ve yöntemlerini incelediği çalışmada, seçmenler için televizyon, gazete yayınları, mitingler ve seçmen ziyaretlerinin önem düzeyinin yüksek olduğu; ilan ve broşür, radyo yayınları, afişler ve internet sitelerinin önem düzeyinin düşük olduğu; ayrıca bu iletişim araç ve yöntemlerinin seçmenlerin tercihlerini belirleme zamanı, oy verdiği parti ve demografik özellikleri bakımından farklılık gösterdiği sonucuna varmıştır. Kentmen (2010) kitle iletişim araçlarının bireysel politik davranışüzerindeki etkisini incelemek için 2006 Eurobarometer anket verilerini kullandığı çalışmada, bireylerin televizyon haberleri ve gazetelere maruz kalma düzeylerinin Avrupa Birliği hakkındaki politik görüşleri üzerinde etkili olduğu sonucuna varmıştır. Tanyıldızı (2012) Elazığ’da 2011 genel seçimleri üzerine yaptığı araştırmada, seçmenlerin en beğendiği siyasal iletişim araçlarının sırasıyla mitingler, politik reklamlar, halk buluşmaları, gazeteler, televizyon tartışma programları ve seçim şarkıları olduğunu belirtmiştir. Akinci ve Akin (2013) Aksaray'da yaptıkları çalışmada, reklam içerikli olmayan yazılı basında yer alan her türlü içerik ve televizyon programı, politik içerikli kitaplar, sempozyum, konferans ve seminerlerden oluşan iletişim faktörünün, seçmen davranışları üzerinde etkili olduğu belirtmişlerdir. Balcı ve Bor (2015) Konya'da yaptıkları çalışmada, seçmenlerin politik bilgi edinme kaynağı olarak önem sırasına göre gazete, televizyon, internet, radyo, mitingler, afiş, ilan ve broşürleri gördükleri; özellikle televizyona verilen önemin parti bağlıı̆̆ı, oy belirleme zamanı ve politik kimlik bakımından farklılık gösterdiği sonucuna varmışlardır. Boyraz ve Erdem (2015) on ili kapsayan, seçmen pazarını bölümlendirmeye yönelik çalışmalarında seçmen pazarının çıkarcı seçmen, umarsız seçmen, kararlı seçmen ve değişime açık seçmen olarak dört gruba ayrıldığını; bu gruplardan medya güdümünde oy verme eğilimi en yüksek olanın değişime açık seçmen olduğu, buna karşın kararlı seçmenlerin medyadan en az etkilenen grup olduğunu belirtmişlerdir.

Balcı ve Sarıtaş (2015) 2014 yerel seçimlerinde Facebook üzerinden politik katılımı incelemek için 454 katılımcıyla gerçekleştirdikleri çalışmada, erkeklerin kadınlara göre Facebook üzerinden daha sık politik katılım gösterdiği ve parti bağııı̆ı ile Facebook üzerinden politik katılım arasında anlamlı ilişki olduğu sonucuna varmışlardır. Arklan (2016) sosyal medyanın politik amaçlı kullanımını incelemek için üniversite öğrencileriyle yaptığı araştırmada, sosyal medya ortamlarının politik konularda çok güvenilir görülmemesine rağmen, politik ilgi arttıkça sosyal medyanın politik tutumlar üzerinde etkili olduğunu vurgulamıştır. Çağlar ve Asığbulmuş (2017) $X$ ve $Y$ kuşaklarının siyasal davranışlarında sosyal medyanın etkisi incelemek için 620 katılımcıyla gerçekleştirdikleri çalışmada, siyasi tercih ile sosyal medyayı takip, sosyal medyanın etkisi ve sosyal medyanın yönlendiriciliği arasında anlamlı bir ilişki olmadığı sonucuna varmışlardır. Aydın ve Gülsoy (2017) siyasi parti liderlerinin sosyal medya paylaşımlarının genç seçmenler üzerindeki etkisi incelemek için786 katılımcıyla gerçekleştirdikleri çalışmada, liderlerin sosyal medya paylaşımlarının genç seçmenler üzerinde etkisinin olmadığı sonucuna varmışlardır. Anıl ve Eti İçli (2017) 2015 genel seçimlerini inceledikleri çalışmada, sosyal medya kullanımı ve online politik katılım arasında pozitif yönlü bir ilişki olduğu sonucuna varmışlardır. Kaya ve Yılmaz (2017) Ankara'da yaptıkları çalışmada, orta sınıf seçmenin karar verme süresi üzerinde partiler hakkındaki televizyon, gazete, dergi ve radyo haberlerinden oluşan politik halkla ilişkiler faktörü ile 
internet sitelerindeki içerik, youtube videoları ve partilerin sosyal paylaşım sitelerinden oluşan internet faktörünün etkili olduğu sonucuna varmışlardır.

Seçmenlerin olduğu kadar politik aktörlerin davranışlarının da özellikle medya içeriklerinden etkilendiği gösteren çalışmalar bulunmaktadır. Bu kapsamda Walgrave ve diğerleri (2008) Belçika'da 1993- 2000 yıllarını kapsayan çalışmalarında, parlamento ve hükümetin politik gündem belirlenmesinde medyanın etkili olduğu ve gazetelerin etkisinin televizyondan daha fazla olduğu; yine Belçika'da Sevenans ve diğerleri (2016) parlamento üyeleri ile yaptıkları çalışmada, siyasi gündemin belirlenmesinde politikacıların medya içeriklerinden etkilendiklerini belirtmişlerdir.

Referandumlarla ilgili çalışmalardan bazıları incelendiğinde; Bowler ve Donovan (2002) Washington ve California'da vatandaş inisiyatifli referandumlar üzerine yaptıkları çalışmada, seçmenlerin bilgi edinme kaynakları olarak önem sırasına göre seçim kitapçıkları, gazeteler, televizyon haber ve reklamları, radyo reklamları ve el ilanı- broşürleri gördükleri; seçmenlerin politik görüşlerine bu bilgi kaynaklarından etkilenme düzeylerinin farklı olduğu; ayrıca özellikle televizyon haber ve reklamları, seçim kitapçıkları ve gazetelerin seçmen davranışları üzerinde etkili olduğunu belirtmişlerdir. Holbolt (2005) Danimarka, İrlanda ve Norveç'i kapsayan çalışmasında, seçmenlerin Avrupa Birliğine katılım referandumundaki oy verme davranışları üzerinde parti üyeliği ve yönetimden memnuniyetin yanı sıra, politik farkındalık sağlayan bilgi kaynaklarının da etkili olduğunu gözlemlemişlerdir. De Vreese ve Semetko (2004) 2000 yılında Danimarka'da yapılan Avrupa Birliği referandumunu inceledikleri çalışmada, kampanya boyunca televizyon programlarının ve haberlerinin, oy verme davranışı üzerinde etkili olduğu sonucuna varmışlardır. De Vreese ve Boomgaarden (2006) Hollanda ve Danimarka'da yaptıkları çalışmada da Avrupa Birliği genişleme sürecine olan kamuoyu desteğinin gazete ve televizyon haberlerinden etkilendiği sonucuna ulaşmışlardır. Schuck ve de Vreese (2011) Almanya'da 2005'de yapılan anayasa değişikliği referandumunu inceledikleri çalışmada, tabloid gazeteler, özel televizyon haberleri ve internet kullanımının referanduma olan destek üzerinde etkili olduğu; Stevens ve Banducci (2013) 2011'de Birleşik Krallık'ta yapılan referandumu inceledikleri çalışmada muhafazakâr, liberal vs. görüşe yakın gazetelerdeki medya içeriğinin seçmen tercihleri üzerinde etkili olduğu sonucuna varmışlardır. Laycock (2013) Birleşik Krallık 'ta 1974-2011 yılları arasında yapılan bazı genel seçimler ve referandumları karşılaştırmalı olarak incelediği çalışmada, genel seçimlere nazaran referandumlardaki oy verme davranışı üzerinde medya okuryazarlığının etkisinin daha belirgin olduğu, farklı gazetelerin okurlarının oy verme davranışı üzerindeki etkisinin farklı olduğu sonucuna varmıştır. 16 Nisan 2017 referandumuyla ilgili az sayıda çalışmadan biri olan, Doğan (2017) Elâzığ’da üniversite öğrencileriyle yaptığı çalışmada, referandumla ilgili bilgi edinme kaynağı olarak sırasıyla en çok internet medyası, televizyon ve gazeteler olarak ifade edildiğini belirtmiştir. 


\section{Araştırmanın Hipotezleri ve Modeli}

Yapılan literatür incelemesi ve kavramsal çerçeve dahilinde araştırmanın test edeceği hipotezleri ve modeli aşağıdaki gibidir;

H1: Mitingler seçmenlerin 16 Nisan 2017 referandumundaki oy tercihleri üzerinde etkilidir.

H2: Liderlerin televizyon konuşmaları seçmenlerin 16 Nisan 2017 referandumundaki oy tercihleri üzerinde etkilidir.

H3: Televizyon tartışma programları seçmenlerin 16 Nisan 2017 referandumundaki oy tercihleri üzerinde etkilidir.

H4: Gazete köşe yazıları seçmenlerin 16 Nisan 2017 referandumundaki oy tercihleri üzerinde etkilidir.

H5: Sosyal medya paylaşımları seçmenlerin 16 Nisan 2017 referandumundaki oy tercihleri üzerinde etkilidir.

H6: Billboard ve afişler seçmenlerin 16 Nisan 2017 referandumundaki oy tercihleri üzerinde etkilidir

Şekil 1: Araştırma Modeli

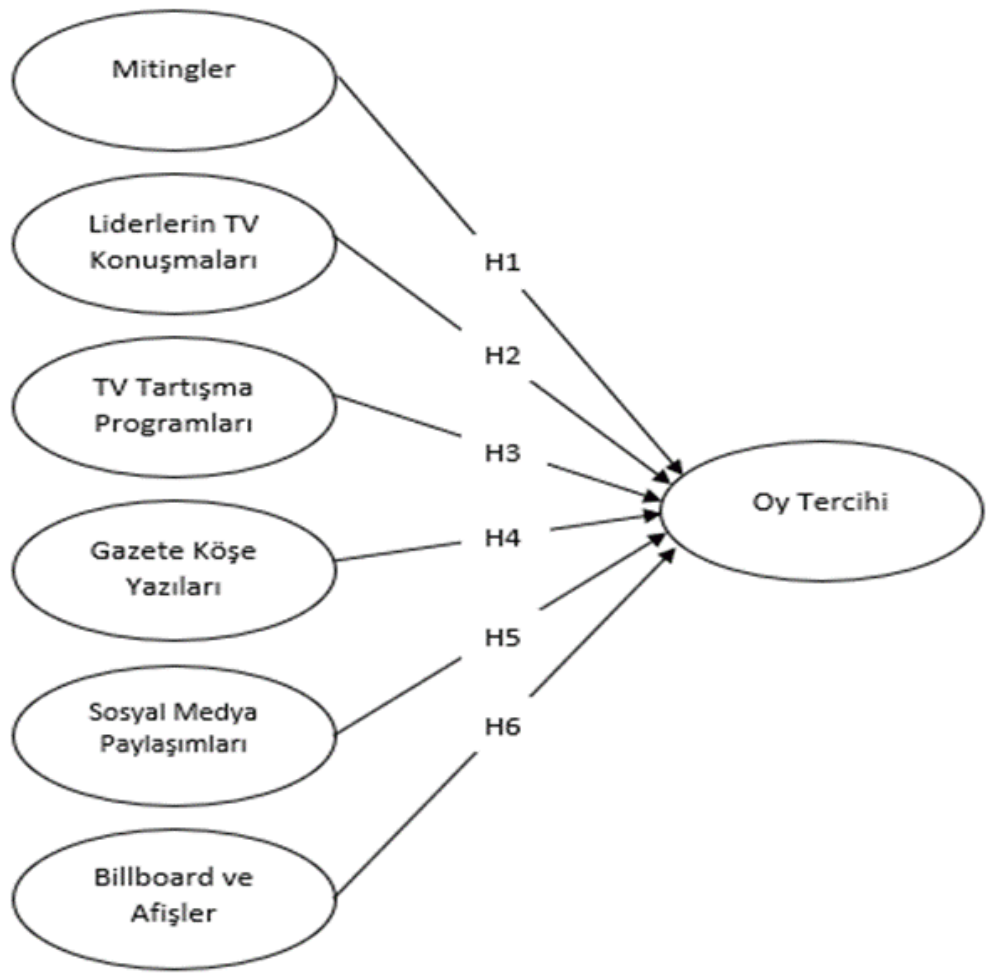

\section{Araştırmanın Kapsamı ve Yöntemi}

Seçmenlerin referandumda oy tercihlerini belirlemede politik iletişim yöntemlerinden hangilerinin ne kadar etkili olduğunu tespit etmek amacıyla Gaziantep’te 495 katılımcıyla yüz yüze anket gerçekleştirilmiştir. Hem zaman hem de maliyet kolaylı̆̆ı bakımından örneklem alma yön- 
temi olarak tesadüfi olmayan yöntemlerden kolayda örneklem yöntemi kullanılmıştır. Araştırmanın ölçüm aracı olarak kullanılan anket formundaki sorular iki bölümden oluşmaktadır. İlk bölümde katılımcıların yaş, cinsiyet, medeni durum, eğitim durumu, aylık gelir ve meslekleriyle ilgili demografik sorular ile referandumda oylanacak maddeleri okuma ve referandumda kullandıkları oyu öğrenmeye yönelik sorular yer almaktadır. İkinci bölümde siyasal iletişim yöntemleri olarak belirlenen mitingler, liderlerin televizyon konuşmaları, televizyon kanallarındaki tartışma programları, gazete köşe yazıları, sosyal medya paylaşımları, billboard ve afişlerden etkilenme düzeylerini ölçmeye yönelik sorular yer almaktadır. Bu bölümde değişkenler, herhangi bir ölçek kullanmak yerine, her bir iletişim aracından etkilenme düzeyi için eşit aralıklı beşli Likert olarak, "1- hiç etkilenmedim" ile "5- çok etkilendim" şeklinde hazırlanmış tek ifadeli sorularla ölçülmüştür.

Bağımsız değişkenler olan politik iletişim yöntemleri eşit aralıklı, bağımlı değişken olan referandumdaki oy tercihi iki kategorili (evet ve hayır) bir değişken olduğundan, verilerin analizinde İkili Lojistik Regresyon analizi kullanılmıştır. İkili Lojistik Regresyon analizi oransal, aralık veya kategorik bağımsız değişkenlerin, iki kategoriden oluşan bir bağımlı değişken üzerindeki etkilerini olasılık olarak hesaplayan bir regresyon yöntemidir (Çokluk, 2010). Diğer regresyon yöntemlerinde olan normal dağılım, doğrusallık ve varyansların homojenliği gibi varsayımların sağlanmasının şart olmadığı, esnek bir yöntem olsa da kategorilerde bulunan birey sayısı, uç değerlerin etkisi, çoklu doğrusal bağlantı ve hata terimlerinin bağımsızlığı gibi bazı kriterleri sağlaması gerekir (Şenel ve Alatli, 2014). Matematiksel olarak olasılık, odds ve logit değerlerine dayanır. Odds, bir olayın olma olasılığının olmama olasılığına oranı; Logit ise odds oranının doğal logaritmasıdır (Peng vd., 2002). Lojistik regresyon modelinin parametreleri tahmin etmek için en yüksek olabilirlik (Maksimum Likelihood) ve Wald istatistikleri kullanılır (Oktay ve Orçanlı, 2014).

$$
\begin{aligned}
& \operatorname{Logit}(Y)=\ln \left(\frac{\pi}{1-\pi}\right)=\alpha+\beta_{1} X_{1} \ldots+\beta_{n} X_{n} \\
& =\frac{e^{\alpha+\beta_{1} X_{1} \ldots+\beta_{n} X_{n}}}{1-e^{\alpha+\beta_{1} X_{1} \ldots+\beta_{n} X_{n}}}
\end{aligned}
$$

1 ve 2 numaralı denklemlerde ikili lojistik regresyon analizinin matematiksel formülleri görülmektedir. Burada; $Y$ bağımlı değişken, $X$ bağımsız değişken, $\pi$ bir olayın bir daha olma olasıIığı, $\alpha$ ise Y'nin kesim noktası, $\beta$ regresyon katsayısıdır (Peng ve So, 2002).

\section{Araştırmanın Bulguları ve Sonuçları}

Araştırmaya katılanların demografik dağılımına bakıldığında, 240 kişi $(\% 48,5)$ kadın, 254 kişi $(\% 51,3)$ erkek; 258 kişi $(\% 52,1)$ evli ve 229 kişi $(\% 46,3)$ de bekardır. Yaş bakımından 7 kişiyle $(\% 1,4)$ en az grup 72 ve üstü, en büyük grup da 294 kişiyle $(\% 59,4) 18-37$ yaş arası bireylerden oluşmaktadır. Öğrenim düzeyleri bakımından 9 kişiyle $(\% 1,8)$ en az grup okula gitmeyen, 203 kişiyle (\%41) en büyük grup lise mezunlarından oluşmaktadır. Aylık gelir bakımından 20 kişiyle (\%4) en az grup 3501-4500 TL gelire sahip bireyler, 187 kişiyle $(\% 37,8)$ en büyük grup 1400TL ve altı gelire sahip bireyler oluşturmaktadır. Meslek açısından en az grup 36 kişiyle $(\% 7,3)$ devlet memurları, en kalabalık grup da 157 kişiyle $(\% 31,7)$ özel sektör- esnaflardan oluşmaktadır.

16 Nisan 2017 tarihinde gerçekleştirilen referandumda oylanması istenen anayasa maddelerini hiç okumadığını ifade eden kişi sayısı $98(\% 19,8)$, bir kısmını okuduğunu ifade eden kişi sayısı 203 (\%41) ve hepsini okuduğunu ifade eden kişi sayısı da $192(\% 38,8)$ olarak; evet oyu verenler 259 kişi $(\% 52,3)$, hayır oyu verenler de 236 kişi $(\% 47,3)$ şeklinde dağılmaktadır. Tablo 1 'de katılımcılara ait tanımlayıcı istatistikler detaylı olarak görülmektedir. 
Tablo 1: Katılımcılara Ait Tanımlayıcı Istatistikler

\begin{tabular}{|c|c|c|c|}
\hline Değişkenler & Gruplar & $f$ & $\%$ \\
\hline \multirow{4}{*}{ Cinsiyet } & Kadın & 240 & 48,5 \\
\hline & Erkek & 254 & 51,3 \\
\hline & Toplam & 494 & 99,8 \\
\hline & Evli & 258 & 52,1 \\
\hline \multirow[t]{4}{*}{ Medeni Hal } & Bekar & 229 & 46,3 \\
\hline & Toplam & 487 & 98,4 \\
\hline & $18-37$ & 294 & 59,4 \\
\hline & $38-52$ & 137 & 27,7 \\
\hline \multirow{6}{*}{ Yaş } & $53-71$ & 55 & 11,1 \\
\hline & 72 ve üstü & 7 & 1,4 \\
\hline & Toplam & 493 & 99,6 \\
\hline & İlk Öğretim & 87 & 17,6 \\
\hline & Orta Öğretim & 41 & 8,3 \\
\hline & Lise & 203 & 41,0 \\
\hline \multirow{6}{*}{ Öğrenim Düzeyi } & Üniversite & 149 & 30,1 \\
\hline & Okula Gitmedim & 9 & 1,8 \\
\hline & Toplam & 489 & 98,8 \\
\hline & 1400 ve Altı & 187 & 37,8 \\
\hline & $1401-2500$ & 162 & 32,7 \\
\hline & $2501-3500$ & 75 & 15,2 \\
\hline \multirow{6}{*}{ Aylık Gelir } & $3501-4500$ & 20 & 4,0 \\
\hline & 4500 ve Üstü & 30 & 6,1 \\
\hline & Toplam & 474 & 95,8 \\
\hline & Devlet Memuru & 36 & 7,3 \\
\hline & Özel Sektör-Esnaf & 157 & 31,7 \\
\hline & Emekli & 38 & 7,7 \\
\hline \multirow{5}{*}{ Meslek } & Öğrenci & 135 & 27,3 \\
\hline & Ev Hanımı & 88 & 17,8 \\
\hline & Diğer & 39 & 7,9 \\
\hline & Toplam & 493 & 99,6 \\
\hline & Hiç Okumadım & 98 & 19,8 \\
\hline \multirow{4}{*}{$\begin{array}{l}\text { Oylanan maddeleri } \\
\text { okuma düzeyi }\end{array}$} & Bir Kısmını Okudum & 203 & 41,0 \\
\hline & Hepsini Okudum & 192 & 38,8 \\
\hline & Toplam & 493 & 99,6 \\
\hline & Evet & 259 & 52,3 \\
\hline \multirow[t]{2}{*}{ Oy Tercihi } & Hayır & 236 & 47,7 \\
\hline & Toplam & 495 & 100,0 \\
\hline
\end{tabular}


Lojistik regresyon analizi gerçekleştirilmeden önce sonuçları uç değerlerin etkisinden arındırmak için tek değişkenli uç değerler grafik yardımıyla, çok değişkenli uç değerler de Mahalonabis uzaklıkları hesaplanarak tespit edilmiş ve analizden çıkartıımıştır. Çoklu doğrusal bağlantı (multicollinearity) probleminin olup olmadığını anlamak için çoklu doğrusal regresyon prosedürünün aynısı kullanılabilmektedir (Menard, 2002). Bu prosedürde bağımsız değişkenler arası korelasyon katsayıları, VIF ve Tolerance değerleri hesaplanmıştır. Modele ait bağımsız değişkenlerde çoklu doğrusal bağlantı problemi olmaması için Tolerance değerinin 0,2 'den büyük, VIF değerinin $10^{\prime}$ dan küçük ve tüm değişkenlere ait VIF değerlerinin ortalamasının 1'den büyük olması gerekmektedir (O’Brien, 2007).

Tablo 2: Değişkenler Arası Çoklu Bağlantı Probleminin incelenmesi

\begin{tabular}{|c|c|c|c|c|c|c|c|c|c|}
\hline Bağımsız değişkenler & 1 & 2 & 3 & 4 & 5 & 6 & Tolerance & VIF & DW \\
\hline 1- Mitingler & 1 & & & & & & 474 & 2,108 & \multirow{6}{*}{1,764} \\
\hline 2- Liderlerin TV Konuşmaları & ,699** & 1 & & & & & ,418 & 2,390 & \\
\hline 3- TV Tartışma programları &, $460 * *$ &, $570 * *$ & 1 & & & & ,576 & 1,736 & \\
\hline 4- Gazete Köşe Yazıları &, $252 * *$ &, $255^{* *}$ &, $444^{* *}$ & 1 & & & 693 & 1,443 & \\
\hline 5- Sosyal Medya Paylaşımları & ,329** &, $383 * *$ &, $361 * *$ &, $452 * *$ & 1 & & 605 & 1,653 & \\
\hline 6- Billboard Ve Afişler &, $467 * *$ &, $433^{* *}$ &, $336 * *$ &, $341 * *$ &, $544^{* *}$ & 1 & 603 & 1,659 & \\
\hline
\end{tabular}

** 0,01 düzeyinde anlamlı

Tablo 2 incelendiğinde VIF ve Tolerance değerlerinin kabul edilir sınırlar içinde olduğu ve tüm VIF değerlerinin ortalamasının 1'den büyük olduğu $(1,831)$ görüldüğü için çoklu doğrusal bağlantı probleminin olmadığına karar verilmiştir. Ayrıca değişkenler arası korelasyon katsayılarının yüksek olmaması da $(r<0,70)$ değişkenler arasında çoklu bağlantının olmadığının bir göstergesidir. Tablo2'de Durbin-watson (DW) istatistiğinin 1,764 olduğu görülmektedir. Bu değerin 2'ye yakın olması hata terimleri arasında yüksek korelasyon ( otokorelasyon) olmadığı anlamına gelmektedir (Eroğlu, 2010).

Lojistik regresyon analizinin varsayımlarının karşılandığı tespit edildikten sonra analizin uygulanmasına geçilmiştir. Bağımlı değişken olan referandumdaki oy tercihi "evet=0" ve "hayır=1" olarak kodlanmıştır. Lojistik regresyon analizi sonuçlarının yorumlanmasına ilk olarak sınıflandırma tablolarının karşılaştııılmasından başlanmaktadır.

Tablo 3: 0. ve 1. Adımlardaki Sınıflandırma Sonuçları

\begin{tabular}{|c|c|c|c|c|c|}
\hline \multirow{6}{*}{ Adım 0} & & & \multicolumn{2}{|c|}{ Tahmin } & \multirow{3}{*}{ Doğru \% } \\
\hline & & & \multicolumn{2}{|c|}{ Oy tercih } & \\
\hline & \multicolumn{2}{|c|}{ Gözlemlenen } & Evet & Hayır & \\
\hline & \multirow{2}{*}{ Oy tercih } & Evet & 259 & 0 & 100,0 \\
\hline & & Hayır & 236 & 0 & 0 \\
\hline & \multicolumn{2}{|c|}{ Toplam \% } & & & 52,3 \\
\hline \multirow{6}{*}{ Adım 1} & \multirow{3}{*}{\multicolumn{2}{|c|}{ Gözlemlenen }} & \multicolumn{2}{|c|}{ Tahmin } & \multirow{3}{*}{ Doğru \% } \\
\hline & & & \multicolumn{2}{|c|}{ Oy tercih } & \\
\hline & & & Evet & Hayır & \\
\hline & \multirow{2}{*}{ Oy tercih } & Evet & 185 & 74 & 71,4 \\
\hline & & Hayır & 86 & 150 & 63,6 \\
\hline & \multicolumn{2}{|c|}{ Toplam \% } & & & 67,7 \\
\hline
\end{tabular}


Tablo 3'de Adım0, bağımsız değişkenlerin eklenmediği başlangıç modelinde tüm katılımcıların evet yanıtını verdiği varsayıldığında, bu tahminin doğruluk oranını göstermektedir. Adım1 ise bağımsız değişkenlerin, bağımlı değişkene ait değerleri doğru tahmin etme oranı göstermektedir. Adım0'daki tahmin \%52,3 olarak bulunmuşken, bağımsız değişkenlerin tahmin oranı \%67,7 olarak gerçekleşmiştir. Bu durum da bağımsız değişkenlerin, başlangıç modelinin tahmin gücünü \%15,4 arttırdığı için modelin uygunluğuna dair bir gösterge oluşturmaktadır.

Tablo 4: Başlangıç Modeline Ait Değerler

\begin{tabular}{cccccccc}
\hline \hline \multirow{3}{*}{ Sabit } & B & S.H. & Wald & sd & $p$ & Exp(B) & -2 Log Likelihood \\
\cline { 2 - 7 } &,- 093 &, 090 & 1,068 & 1 &, 301 &, 911 & 685,147 \\
\hline \hline
\end{tabular}

Tablo 4'de bağımsız değişkenlerin yer almadığı başlangıç modeline ait değerler görülmektedir. Özellikle buradaki -2 Log Likelihood değeri, bağımsız değişkenlerin eklenmesiyle oluşan modelin -2 Log Likehood değeriyle karşılaştırılarak modelin değerlendirilmesine yardımcı olur.

Modelin uygunluğunun değerlendirilmesinde uyum iyiliği testlerinden de yararlanılır. Bu testler Skore (hata ki-kare) test, Omnibüs test ve Hosmer \& Lemeshow testleridir. Skore testi sonucunun anlamlı çıkması, modelde yer almayan bağımsız değişkenlerin tamamının ya da bazılarının modele eklenmesinin modelin tahmin gücünü arttıracağı anlamına gelmektedir. Omnibüs testi ki-kare değerinin anlamlı olması, bağımsız değişkenlerin olduğu modelin başlangıç modelinden daha iyi olduğu ve bağımsız değişkenler ile bağımlı değişkenler arasında ilişkinin varlığını gösterir. Hosmer \& Lemeshow testi ise lojistik regresyon modelini bir bütün olarak değerlendirir. Test sonucunun anlamsız $(p>0,05)$ çıkması model- veri uyumunun iyi olduğunu göstermektedir (Çokluk, 2010). Tablo 5'de bu testlere ait değerler görülmektedir.

Tablo 5: Uyum Iyiliği Test Sonuçları

\begin{tabular}{lccc}
\hline \multicolumn{1}{c}{ Test } & $X^{2}$ & Sd & $p$ \\
\hline Score Test & 76,193 & 6 &, 000 \\
Omnibüs Test & 80,949 & 6 &, 000 \\
Hosmer \& Lemeshow Test & 7,734 & 8 &, 460 \\
\hline \hline
\end{tabular}

Tablo 5 incelendiğinde Score test ve Omnibus test ki- kare değerlerinin anlamlı $(p<0,01)$, Hosmer \& Lemeshow test ki-kare değerinin de anlamsız $(p>0,05)$ çıktığı görülmekte, bu da modelin uyum iyiliği kriterlerini sağladığı anlamına gelmektedir.

Lojistik regresyon modelindeki bağımsız değişkenlerin, bağımlı değişkendeki varyansın ne kadarını açıkladığını Cox \& Snell $R^{2}$ ve Nagelkerke $R^{2}$ değerleri göstermektedir. Bu değerler çoklu doğrusal regresyondaki $R^{2}$ değeri gibi yorumlanır. $R^{2}$ değerinin 1 olması mükemmel uyumu ve açıklama gücünü ifade eder. Cox $\&$ Snell $R^{2}$ değerinin üst limitinin 1 olmaması, buna karşın Nagelkerke $R^{2}$ değerinin 0 ile 1 arasında değer almasından dolayı Nagelkerke $R^{2}$ değerinin yorumlanması önerilmektedir (Hair vd., 2014). Modele ait Cox \& Snell $R^{2}=0,151$ ve Nagelkerke $R^{2}=0,201$ olarak bulunmuştur. Bu da modelin toplam varyansın \%20,1'ini açıkladığını göstermektedir.

Lojistik regresyon analizinin sonuçlarının değerlendirilmesinde son aşama regresyon katsayıları ve bunların anlamlılık düzeylerinin incelenmesidir. Tablo 6 ' da değişkenlere ait $\beta$, Standart hata ve Wald istatistiklerine ait değerler gösterilmektedir. Burada $\beta$ değişkenlere ait regresyon katsayılarını ifade eder. Katsayıların işaretinin negatif olması 0 ile kodlanmış durumun gerçekleşme olasılığını, pozitif olması da 1 ile kodlanmış durumun gerçekleşme olasılığı üzerinde etkisi 
olduğu şeklinde yorumlanır. Wald istatistiği, regresyon katsayılarının anlamlılı̆ının test edilmesine yarayan bir yöntemdir. Doğrusal regresyondaki t istatistiğine benzer. Bu değer, değişkenlerin $\beta$ katsayılarının standart hatalarına bölünmesiyle elde edilen değerin karesinin alınması şeklinde hesaplanır $\left.\left(\frac{\beta}{S . H}\right)^{2}\right)$. Tabloda yer alan bir başka değer de $\operatorname{Exp}(\beta)$ değeridir ve her bir değişken için hesaplanan Odss oranını temsil eder. Bağımsız değişkenlerdeki 1 birimlik değişimin Odds oranında meydana getirdiği değişimi ölçer. $\operatorname{Exp}(\beta)$ değeri 1'den büyükse tahmin edilmeye çalışılan durumun olma, 1'den küçükse olmama olasılığını arttırdı şeklinde yorumlanır (Field, 2005).

Tablo 6: Lojistik Regresyon Modelinin Katsayı Tahminleri

\begin{tabular}{|c|c|c|c|c|c|c|c|}
\hline \multirow{2}{*}{ Değişkenler } & \multirow{2}{*}{$\beta$} & \multirow{2}{*}{ S.H. } & \multirow{2}{*}{ Wald } & \multirow{2}{*}{ sd } & \multirow{2}{*}{$\operatorname{Exp}(\beta)$} & \multicolumn{2}{|c|}{ Exp( $\beta) \% 95$ Güven Aralığı } \\
\hline & & & & & & Alt sınır & Üst sınır \\
\hline Mitingler &,$- 247^{*}$ & 102 & 5,904 & 1 & 781 & 640 & ,953 \\
\hline Liderlerin TV Konuşmaları &,$- 465^{* *}$ & 114 & 16,713 & 1 & 628 & ,502 & 785 \\
\hline TV Tartışma Programları & 007 & 105 & ,004 & 1 & 1,007 & 819 & 1,238 \\
\hline Gazete Köşe Yazıları &, $302 * *$ & 107 & 7,970 & 1 & 1,352 & 1,097 & 1,667 \\
\hline Sosyal Medya Paylaşımları & 017 & ,099 & 030 & 1 & 1,017 & ,838 & 1,234 \\
\hline Billboard Ve Afişler &,- 076 & 104 & ,541 & 1 & 927 & ,756 & 1,135 \\
\hline Sabit & 1,418 & ,323 & 19,247 & 1 & 4,130 & & \\
\hline \multicolumn{8}{|l|}{ Cox \& Snell $R^{2}=, 151$} \\
\hline \multicolumn{8}{|l|}{ Nagelkerke $R^{2}=, 201$} \\
\hline-2 Log Likelihood $=604,198$ & & & & & & & \\
\hline
\end{tabular}

** 0,01 düzeyinde anlamlı; * 0,05 düzeyinde anlamlı

Tablo 6'daki regresyon katsayıları ve anlamlılık düzeylerine bakıldığında, bağımlı değişken olan "referandum oy tercihi" üzerinde, bağımsız değişkenlerden Mitingler $(\beta=-0,247 ; p<0,01)$, Liderlerin Televizyon Konuşmaları $(\beta=-0,465 ; p<0,01)$ ve Gazete Köşe Yazılarının $(\beta=0,302$; $p<0,01$ ) istatistiksel olarak anlamlı etkilerinin olduğu, bu nedenle $H 1, H 2$ ve $H 4$ hipotezlerinin kabul edildiği görülmektedir. Diğer değişkenlerin etkilerinin istatistiksel olarak anlamsız çıkması nedeniyle $\mathrm{H} 3, \mathrm{H} 5$ ve $\mathrm{H} 6$ hipotezleri reddedilmiştir.

$\operatorname{Exp}(\beta)$ değerlerine bakıldığında, seçmenlerin evet oyu kullanma durumları üzerinde $\operatorname{Exp}(\beta)$ değerleri 1'den küçük olduğu için liderlerin televizyon konuşmaları $(\operatorname{Exp}(\beta)=0,628)$ ve Mitinglerin $(\operatorname{Exp}(\beta)=0,781)$, hayır oyu kullanma durumları üzerinde de $\operatorname{Exp}(\beta)$ değeri 1'den büyük olduğu için Gazete Köşe Yazılarının $(\operatorname{Exp}(\beta)=1,352)$ etkili olduğu görülmektedir. Başka bir ifadeyle, Liderlerin Televizyon Konuşmalarından etkilenme düzeyindeki bir birimlik artışın evet oyu verme olasılığını \%37 ([0,628 - 1]x100), Mitinglerden etkilenme düzeyindeki bir birimlik 
artışın evet oyu verme olasılığını \%21,9 ([0,781 - 1]x100) ve Gazete Köşe Yazılarından etkilenme düzeyindeki bir birimlik artışın da hayır oyu kullanma olasılığını \%35,2 ([1,352 - 1]x100) arttırdığı sonucuna varılmıştır.

\section{Sonuç ve Değerlendirme}

16 Nisan 2017 referandumu, Anayasada yaptığı değişiklikler ve kampanya dönemi boyunca yaşanan tartışmalar dolayısıyla ülke siyasi tarihi açısından oldukça önemli bir yer tutmaktadır. Değiştirilmek istenen maddelerin teknik hukuksal ve siyasal içerikli olması ve referandum oylamalarına seçmenlerin pek alışkın olmaması, seçmenlerin odak noktasını oylamanın içeriğinden çok siyasi gündeme kaydırmıştır. Bir süredir siyasal kutuplaşmanın ülke geneline hâkim olması, bu referandumda politik partileri ve siyasi aktörleri evet bloğu ve hayır bloğu olarak ikiye ayırmış ve tüm kampanya bu iki bloğun seçmenleri etkileme mücadelesi şeklinde geçmiştir. Seçmenin ilgisinin maddelerin içeriğinden çok siyasal gündeme yoğunlaşması ve normal seçimlerin aksine $\% 50+1$ oy alan bloğun kazanacak olması, tek bir oyu bile çok önemli hale getirmiştir. Bu sebeple politik mesajların ve propaganda içeriklerinin mümkün olan en çok seçmene ve bu mesajların etkili bir şekilde iletilmesi hayati önem kazanmıştır. Dolayısıyla propaganda aracı olarak kullanılan iletişim araçları da önemli hale gelmiştir.

Siyasal iletişim araçlarının 2017 referandumunda seçmenlerin oyları üzerindeki etkisini incelemek için Gaziantep'te 495 katılımcıyla anket yapılmış, elde edilen veriler ikili Lojistik Regresyon yöntemiyle analiz edilmiştir. Analiz sonucunda mitingler ve liderlerin televizyon konuşmalarının evet oyları üzerinde, gazete köşe yazılarının da hayır oyları üzerinde istatistiksel olarak etkili olduğu görülmüştür. Diğer iletişim yöntemleri olan televizyon tartışma programları, sosyal medya paylaşımları, billboard ve afişlerin etkileri ise istatistiksel olarak anlamlı bulunmamıştır.

Mitingler ve liderlerin televizyon konuşmalarının evet oyu üzerinde etkili olması, genellikle mitinglerin liderler tarafından yapıldığı da dikkate alındığında, diğer politik pazarlama öğelerinden daha fazla, liderlerin seçmen üzerinde etkili olduğu ve evet bloğundaki liderlerin seçmenleri etkilemede daha başarılı olduğu sonucu çıkarılabilir. Benzer şekilde televizyon tartışma programlarının etkisinin istatistiksel olarak anlamsız olması, bu programlarda liderler yerine genellikle uzman, yorumcu ya da liderlere nazaran daha düşük profilli siyasetçilerin yer alması, liderlerin etkisinin diğer aktörlerden çok daha belirleyici olmasının bir göstergesi olarak değerlendirilebilir. Sosyal medya paylaşımlarının etkisi anlamsız çıkarken, gazete köşe yazılarının anlamlı çıkması, seçmenlerin sosyal medyadaki içeriğe oy tercihlerini belirleyecek kadar güvenmedikleri; bunun yerine kim olduğunu ve hangi görüşe yakın yayın organında yazdığını bildikleri figürlerin görüşlerinden etkilenebildikleri anlamına gelmektedir. Son olarak billboard ve afişlerin etkisinin istatistiksel olarak anlamsız çıkması, bu iletişim yönteminin günümüzde demode olduğu ve bu yöntemlere ayrılan bütçenin diğer etkili politik pazarlama araçlarına aktarılmasının politik başarı açısından daha etkili olabileceği sonucu çıkarılabilir.

Çalışmada elde edilen sonuçlar ilgili literatüre katkı sağlamakla birlikte bazı sınırlılıklarda barındırmaktadır. Bunların başında araştırmanın sadece Gaziantep ve 495 kişi ile sınırlı olması gelmektedir. Sonraki araştırmalarda daha fazla bölge ve katılımcıyla gerçekleştirilmesi, araştırmanın genelleştirilmesine katkı sağlayacaktır. Bir diğeri ise iletişim yöntemlerinin altı taneyle sınırlı olmasıdır. Iletişim yöntemlerinin arttırılması ve detaylandırılması bu çalışmada elde edilen sonuçların derinleştirilmesine katkı sağlayacaktır. 


\section{Eskişehir Osmangazi Üniversitesi IïB Dergisi}

\section{Kaynaklar}

Akinci, Mehmet; Akin, Eyüp (2013), "Siyasetin Gösterileşmesi, Lider Olgusu ve Seçmen Tercihi", Ekonomik ve Sosyal Araştırmalar Dergisi, 9(2), 329-352.

Anıl, Nihat Kamil; Eti İçli, Gülnur (2017), "Sosyal Ağ Kullanımı ve Siyasi İlgi Bağlamında Gençlerin Onlıne Siyasi Katılımı", Kırklareli Üniversitesi İktisadi ve Idari Bilimler Fakültesi Dergisi, 6(3), 87-96.

Arklan, Ümit (2016), "Sosyal Medyanın Siyasal Amaçıı Kullanımı: Ağ Kuşağının Kullanım Alışkanlıkları Üzerine Bir Araştırma", Gümüşhane Üniversitesi İletişim Fakültesi Elektraonik Dergisi, 4(2), 618-657.

Avcı, Kemal; Hülür, Himmet (2017), "Siyasal Kampanyalarda Kullanılan İletişim Araçlarının Seçmen Açısından Önemi: 2017 Anayasa Değişikliği Halkoylaması Bolu Araştırması", Turkish Studies, 12(24), 17-32.

Aydın, Sonay Zeki; Gülsoy, Sunay (2017) "Siyasi Parti Liderlerinin Sosyal Medya Kullanımının Genç Seçmenler İçin Önemi : Süleyman Demirel Üniversitesi Öğrencileri Üzerinde Bir Uygulama", Süleyman Demirel Üniversitesi Iktisadi ve Idari Bilimler Fakültesi Dergisi, 22(4), 965-979.

Balcı, Şükrü; Bor, Tuna (2015), "Siyasal Bilgilenmede Televizyonun Önem Düzeyi : Üniversite Öğrencileri Üzerine Bir inceleme", Global Media Journal TR Edition, 5(10), 47-70.

Balcı, Şükrü; Sarıtaş, Hamide (2015), "Facebook ve Siyasal Katılım: 2014 Yerel Seçimleri Araştırması", Türkiyat Araştırmaları Dergisi, (37), 511-535.

Bowler, Shaun; Donovan, Todd (2002), "Do Voters Have a Cue? Television Advertisements as a Source of Information in Citizen-İnitiated Referendum Campaigns", European Journal of Political Research, 41(6), 777-793. doi:10.1111/1475-6765.t01-1-00031

Boyraz, Elif; Erdem, Orhan (2015), "Siyaset Pazarında Bölümlendirme Üzerine Keşifsel Bir Araştırma", Yönetim ve Ekonomi, 22(1), 61-81.

Brians, Craig Leonard; Wattenberg, Martin P. (1996), "Campaign Issue Knowledge and Salience: Comparing Reception from TV Commercials, TV News Ans Newspapers", American Journal of Political Science, 40(1), 172-193. doi:10.2307/2111699

Çağlar, Nedret; Asığbulmuş, Hasan (2017), "X ve Y Kuşaklarının Siyasal Davranışında Sosyal Medyanın Etkisi : Gaziosmanpaşa İlçesinde Bir Araştırma", Süleyman Demirel Üniversitesi Sosyal Bilimler Enstitüsü Dergisi, 4(29), 85112.

Çavuşoğlu, Hüseyin; Pekkaya, Mehmet (2015) "Siyasal Propaganda Araçlarının Seçmen Tercihine Etkisi: Zonguldak Örneği", Eskişehir Osmangazi Üniversitesi libf Dergisi, 10(3), 91-115.

Çokluk, Ömay (2010), "Lojistik Regresyon Analizi: Kavram ve Uygulama", Kuram ve Uygulamada Eğitim Bilimleri, 10(3), 1357-1407.

De Vreese, Claes H.; Boomgaarden, Hajo G. (2006), "Media Effects on Public Opinion about the Enlargement of the European Union", Jcms Journal Of Common Market Studies, 44(2), 419-436. doi:10.1111/j.14685965.2006.00629.x

De Vreese, Claes H.; Semetko, Holli A. (2004), "News Matters: Influences on the Vote in the Danish 2000 Euro Referendum Campaign", European Journal of Political Research, 43(5), 699-722. doi:10.1111/j.03044130.2004.00171.x

Doğan, Adem (2017), "2017 Referandumunda Genç Seçmenlerin Siyasal Tercihlerine ilişkin Bir İnceleme: Fırat Üniversitesi Örneği", Turkish Studies, 12(12), 75-94.

Druckman, James N. (2005), "Media Matter: How Newspapers and Television News Cover Campaigns and Influence Voters", Political Communication, 22(4), 463-481. doi:10.1080/10584600500311394

Eroğlu, Abdullah (2010), "Çok Değişkenli İstatistik Tekniklerin Varsayımları", Ş. Kalaycı (Ed.), SPSS Uygulamalı Çok Değişkenli İstatistik Teknikleri içinde (5. bs., ss. 205-233). Ankara: Asil Yayın Dağıtım.

Eroğlu, A. Hüsrev; Bayraktar, Sumru (2010), "Siyasal Pazarlama Uygulamalarının Seçmen Tercihleri Üzerine Etkileri İzmir İli Örneği", Süleyman Demirel Üniversitesi Sosyal Bilimler Enstitüsü Dergisi, 2(12), 187-207.

Eveland, William P.; Scheufele, Dietram A. (2000), "Connecting News Media Use with Gaps in Knowledge and Participation", Political Communication, 17(3), 215-237. doi:10.1080/105846000414250

Field, Andy (2005), " Discovering statistics using SPSS", (D. B. Wright, Ed.) (2. bs.). London: Sage Publications.

Hair, Joseph F.; Black, William C.; Babin, Barry J., Anderson, Rolph E. (2014), "Multivariate Data Analysis", Prentice-Hall, Inc (7. bs.). Harlow: Pearson Education Limited. doi:10.1038/259433b0 
Holbolt, Sara Binzer (2005), "When Europe matters: The İmpact of Political Information on Voting Behaviour in EU Referendums", Journal of Elections, Public Opinion \& Parties, 15(1), 85-109. doi:10.1080/13689880500064635

Kalender, Ahmet (2003), "Seçmenlerin Karar Sürecinde İletişim Araç ve yöntemlerinin Önemi Üzerine Bir Araştırma", Selçuk Iletişim, 2(4), 30-41.

Kaya, Fatma; Yılmaz, Kadri Gökhan (2017), "Politik Pazarlamada Tutundurma Faaliyetlerinin Orta Sınıfta Yer Alan Seçmenin Karar Verme Noktasındaki Düşünme Süresi Üzerine Etkisi: Ankara İlinde Bir Araştırma", Akademik Sosyal Araştırmalar Dergisi, 5(45), 452-469.

Kentmen, Çiğdem (2010), "Mass Media Use and Citizens' Knowledge About The EU: The Turkish Case", Turkish Studies, 11(4), 625-641. doi:10.1080/14683849.2010.540117

Laycock, Samantha (2013), "Is Referendum Voting Distinctive? Evidence from Three UK Cases", Electoral Studies, 32(2), 236-252. doi:10.1016/j.electstud.2012.10.012

LeDuc, Lawrence (2000), "Referendums and Elections: How Do Campaigns Differ?" The Political Consequences of Modern Electioneering içinde (ss. 1-35). Copenhagen: University of Copenhagen.

LeDuc, Lawrence (2002), "Opinion Change and Voting Behaviour in Referendums", European Journal of Political Research, 41(6), 711-732. doi:10.1111/1475-6765.00027

Menard, Scott (2002), "Applied Logistic Regression Analysis", (C. D. Loughton ve D. Santoyo, Ed.)Sage (2. bs.). Thousand Oaks: Sage. doi:10.4135/9781412983433

O’Brien, Robert M. (2007), "A Caution Regarding Rules of Thumb for Variance Inflation Factors", Quality and Quantity, 41(5), 673-690. doi:10.1007/s11135-006-9018-6

Oktay, Erkan; Orçanlı, Kenan (2014), "Atatürk Üniversitesinde İnternet Bankacılığının Kullanımını Etkileyen Faktörlerin Belirlenmesi", Uşak Üniversitesi Sosyal Bilimler Dergisi 2014, 7(2), 57-91.

Özdemir, Gürbüz (2017), "16 Nisan 2017 Halk Oylaması ve Halk Oylaması Sürecinin Siyaset Bilimi ve Kamu Yönetimi Bölümü Öğrencileri Tarafından Algılanmasına İlişkin Bir Araştırma : Çankırı Karatekin Üniversitesi Örneği", Çankırı Karatekin Üniversitesi Iktisadi ve Idari BilimlerFakültesi Dergisi, 7(2), 247-280. doi:10.18074/ckuiibfd.372403

Peng, Chao-Ying Joanne; Lee, Kuk Lida; Ingersoll, Gary M. (2002), "An Introduction to Logistic Regression Analysis and Reporting", The Journal of Educational Research, 96(1), 3-14. doi:10.1080/00220670209598786

Peng, Chao-Ying Joanne; So, Tak-Shing Harry (2002), "Logistic Regression Analysis and Reporting: A Primer", Understanding Statistics, 1(1), 31. doi:10.1207/S15328031US0101

Quinlan, Stephen; Shephard, Mark; Paterson, Lindsay (2015), "Online Discussion and the 2014 Scottish Independence Referendum: Flaming Keyboards or Forums for Deliberation?", Electoral Studies, 38, 192-205. doi:10.1016/j.electstud.2015.02.009

Schuck, Andreas R.T.; de Vreese, Claes H. (2011), "Public Support for Referendums: The Role of the Media", West European Politics, 34(2), 181-207. doi:10.1080/01402382.2011.546566

Sevenans, Julie; Walgrave, Stefaan; Joanna Epping, Gwendolyn (2016), "How Political Elites Process Information From the News: The Cognitive Mechanisms Behind Behavioral Political Agenda-Setting Effects", Political Communication, 33(4), 605-627. doi:10.1080/10584609.2016.1153543

Stevens, Daniel; Banducci, Susan (2013), "One Voter and Two Choices: The İmpact of Electoral Context on the 2011 UK Referendum", Electoral Studies, 32(2), 274-284. doi:10.1016/j.electstud.2012.10.005

Şenel, Selma; Alatli, Betül (2014), "Lojistik Regresyon Analizinin Kullanıldığı Makaleler Üzerine Bir İnceleme", Eğitimde ve Psikolojide Ölçme ve Değerlendirme Dergisi, 5(1), 35-52. doi:10.21031/epod.67169

Tan, Ahmet (2002), "ilke ve Uygulamalarıla Politik Pazarlama "(1. bs.), istanbul: Papatya Yayıncılık.

Tanyıldızı, Nural İmik (2012), "Siyasal İletişimde Müzik Kullanımı: 2011 Genel Seçim Şarkılarının Seçmene Etkisi", Selçuk iletişim, 7(2), 97-110.

Walgrave, Stefaan; Soroka, Stuart; Nuytemans, Michiel (2008), "The Mass Media's Political Agenda-Setting Power: A Longitudinal Analysis of Media, Parliament, and Government in Belgium (1993 to 2000)", Comparative Political Studies, 41(6), 814-836. doi:10.1177/0010414006299098 
Eskişehir Osmangazi Üniversitesi IïBF Dergisi 